\title{
An Empirical Study on the Impact of Environmental Tax and Government Innovation Subsidy on Enterprise Green Process Innovation
}

\author{
Liu Haiyun* Li Yue Song Dan \\ School of management, Hunan University of Technology and Business ,Changsha,410205,China; \\ liu_hy@hutb.edu.cn(Liu.HY);201810310027@stu.hutb.edu.cn(L.Y);3146356682@qq.com(S.D) \\ *Correspondence: liu_hy@hutb.edu.cn ;Tel.: +86-189-7584-0393
}

\begin{abstract}
China is in the climbing phase of the "Inverted U" environmental Kuznets curve, from excessive environmental consumption to the development stage of governance and protection, and green innovation. It is the most complex period of environmental quality. Environmental and policy regulation are very important. Select panel data of 29 provinces of China (excluding Hong Kong, Macau, Taiwan, Hainan and Tibet) from 2008 to 2017, construct a nonlinear two-threshold regression model, empirically analyse the impact of environmental tax and government innovation subsidies to green processes innovation, and attempt to explore whether the implementation of these two policies at the same time can make enterprises more inclined to green process innovation and whether there is an optimal space for policy implementation. It is proposed that the synergy effect of environmental tax and government innovation subsidy policies on enterprise green process innovation should be fully utilized, and the enterprise green process innovation environment and incentive mechanism should be improved to promote the green transformation and sustainable development of enterprises.
\end{abstract}

Keywords: Environmental Tax; Government Innovation Subsidy; Green Process Innovation; Double Threshold Model

\section{Introduction}

Since the reform and opening-up, China's economy has grown rapidly, but the constraints of the natural ecological environment have become increasingly prominent. At present, China is in the three-phase of the superimposition of the critical period and the transitional phase of industrial civilization to ecological civilization. Facing the urgent need of environmental protection, it is also necessary to ensure the green transformation of production and lifestyle. Green technology innovation is an important approach to achieve this dual goals. Green technology innovation has a 
spillover effect. Enterprises are the main body to practice green development and green technology innovation. However, enterprises lack the internal driving force for investing in independent green technology innovation. The government needs to formulate corresponding policy support system to stimulate and promote. The Fourth Plenary Session of the Nineteenth Central Committee of the Communist Party of China made it clear that the green production system and policy guidance should be improved to promote the development of green technological innovation in enterprises. Provide products, processes, services and market solutions through innovation, reduce natural resource consumption, and "force" enterprises to reckon in resource and environmental costs into production costs through the regulation mechanism, and continuously increase the demand for pollution control technologies and green processes, thus promote in-depth research and development in the green field and the effective supply of eco-friendly products. Environmental tax and government innovation subsidies are two important environmental regulation policies that promote green innovation and affect the direction of technological innovation. This article analyzes and verifies the impact of the simultaneous implementation of these two policies on enterprise process innovation and whether there is a modest range of policy effects.

\section{Review and Hypotheses}

From the perspective on environmental regulation and enterprise green technology innovation.Poter (1995) believes that the technological innovation of enterprises will be positively affected by environmental protection, and then affect the competitiveness of enterprises. Margat (1978) proposed that technological innovation can serve as an important factor balancing environmental protection and corporate performance. Research on environmental tax and enterprise green technology innovation, On the one hand, studies have shown that environmental tax can directly bring about the effect of reducing environmental pollution. Tullock (1967), Kneese \& Bower (1968), Terkla (1984) and other scholars gradually developed the idea that environmental taxes have "excess returns" in the process of studying water resources. Pearce (1991) also pointed out that the use of environmental taxes to replace some of the distorted taxes, while reducing economic activities that damage the environment, can also avoid further losses in tax efficiency. On the other hand, $\mathrm{Li}$ and $\mathrm{He}(2018)$ proposed that the relationship between environmental tax and corporate green technology innovation is “ inverted U. However, 
Leeuween et al. (2013) explained that environmental regulation policies will have an “crowding-out effect" on corporate R\&D investment and thus negatively affect corporate green technology innovation.Some researchers studied the relationship of government innovation subsidies and enterprise green technology innovation.Chen et al. (2019) studied the regulatory effect of government subsidies on environmental regulation and green technology innovation, but it had a direct negative effect on green technology innovation. Acemolgu et al. (2012) pointed out that government innovation subsidies can promote green technology innovation of enterprises. Duan et al. (2016) showed that the effect of government green technology innovation subsidies has certain uncertainties, and even high subsidies sometimes inhibit the cooperation between enterprises. Liu et al. (2019) proposed that government subsidies will produce " crowding-out effect” and “substitution effect”, thereby affecting enterprises' own investment in green technology innovation. Then,the research on the interaction between environmental tax and government innovation subsidies.Qin (2012) suggested that government should promote green technology innovation and industrialization by improving fiscal and financial policies, provide support and guarantee for green technology innovation. Li (2014) proposed that environmental tax policy and green technology innovation subsidy policy should be used in combination, and through establishing an environmental tax rebate mechanism, and policy support should be given to enterprises in the process of transition to green growth. Xu (2017) used a game model to prove that when manufacturing enterprises make decisions to green innovation,government innovation subsidies and carbon tax collection will have an effect.

In summary, the academic community has carried out theoretical and practical studies on the relationship between environmental tax, government subsidies and enterprise green technology innovation.and has achieved remarkable results, but there are still some limitations: there are more studies on the relationship between environmental tax, government innovation subsidies and corporate green innovation. There is a lack of mechanism and empirical analysis of the three. Linear models is often use in the research methods,but the economic laws may be non-linear and their functional form may change depending on a certain threshold variable, especially during the period of economic transformation (Shi,2018). Based on this, this article puts environmental tax, government innovation subsidies and enterprise green process innovation in the same framework, and construct a nonlinear double-threshold regression model for empirical analysis, trying to explore whether the implementation of these two policies at the same time can make enterprises 
prefer for green process innovation and whether there is an optimal space for policies effects.

\section{Hypotheses}

\subsection{The impact of environmental tax on enterprise green process innovation}

Environmental taxes directly increase the cost of enterprises, prompting enterprises to take Consider the external cost in the decision-making, which has a negative impact on output, but it can fundamentally promote enterprise to use environmental resources and reduce waste emissions . If the government adopts a low environmental tax, enterprises may have two options: One is that enterprises do not carry out green process innovation, because the cost increase caused by environmental tax is not obvious, and far less than the cost of green process innovation, or may cause further environmental pollution if take other methods to conduct some pollutants; Second is that enterprises carry out part of green process innovations and select those process parts which are easier to change or have obvious effects in the short term, so as to reduce the cost increase caused by environmental taxes. Although it has a certain effect, it failed to achieve green innovation fundamentally or as a whole. If the government adopts high environmental taxes, enterprises may also face two options: one is that enterprises are forced to carry out part of green process innovation under tax pressure; the other is that enterprises have enhanced their awareness of environmental protection and carried out large-scale green process innovation. However,because this investment cannot make a profit in a short-term, enterprise should bear the cost of environmental tax while increasing input costs. In this case,enterprises may choose not to innovate in short term because they cannot afford the increased cost. Based on this, the following assumption is:

H1: The implementation of the environmental tax policy alone has a negative impact on the green process innovation of enterprises.

\subsection{The impact of government innovation subsidies on enterprise green process} innovation

There are two main impacts of government innovation subsidies on enterprise green process innovation: The first is positive impact, government R\&D subsidies can promote enterprise innovation, because it's subsidies can ease the financing constraints of enterprises, share the risk of innovation failure, and bridge the gap between the private and social benefits rates ( $\mathrm{Li}, 2019)$; The second is negative impact. The government is often unable to select projects effectively which 
are worth subsidizing because of asymmetric information. Therefore, it is possible to invest projects inefficiently, that is, adverse selection in advance. At the same time,enterprises without strong supervision may may use subsidized funds for non-research and development purposes, that is, post-mortem moral hazard (Antonelli \& Crespi, 2011). Therefore, there may be an optimal range of government innovation subsidies, which makes the positive effects of government innovation subsidies optimal and the negative effects minimal. If the government implements low innovation subsidies, enterprises may face two choices: First, the awareness of environmental protection and green process innovation is enhanced, but this investment may continue to increase costs, and enterprises may give up in the process of innovation; Second, enterprises do not invest in green process innovation, because the amount of subsidies is far less than the cost of green process innovation. If the government implements a high innovation subsidies, enterprises may also have two options: First, enterprises will carry out green process innovation. Under the premise of subsidies, the increased costs will not cause problems to the company's business in the short term; Second, enterprises only carry out a small part of green process innovations. Based on the above analysis, the following assumptions is:

H2: The government innovation subsidy policy will promote enterprises to prefer green process innovation and the effect of policy implementation has a moderate range.

3.3 The impact of environmental tax and government innovation subsidies on enterprise green process innovation

Green process innovation has high risks because development and promotion not only involve large investments, but also have high operating costs. Both environmental tax and government innovation subsidies guide enterprises to carry out green process innovation, and the two have different effects on enterprises. Excessive pressure of cost increasing will affect the normal operation of enterprises, and different levels of government innovation subsidies will also have different effects on the green innovation behavior of enterprises. Appropriate government innovation subsidies will also ease the pressure of enterprises on green innovation. Under the joint influence of the two, the effect on green innovation of enterprises will be different from the effect of using only one policy or two separately. If government only adopts environmental tax policy and does not subsidize the green process innovation, then enterprises have two options: One is that enterprises do not carry out green process innovation and bear the increased costs of environmental tax; the other is that enterprises carry out green process innovation, will increase 
investment in the short term, but in the long run, will offset the costs of environmental regulations. If the government adopts environmental tax policy and provide green process innovation subsidies at the same time. Then enterprises face three options. First, enterprises choose not to innovate, because government subsidies can compensate for the increased cost of environmental taxes. Second, innovation just in some products or processes, because government subsidies cannot compensate for the increased costs of environmental taxes, and it is less than the long-term costs of noR\&D. Third, enterprises choose to carry out green process innovation, transform and update production equipment, and study waste recycling methods. Based on the above discussion, the following hypotheses is:

H3: The impact of environmental tax and government innovation subsidies on enterprise green process innovation is nonlinear, and when the two policies interact with each other, it will promote enterprise green process innovation.

\section{Data sources and variable measurement}

\subsection{Data source}

Select panel data of industries above designated size in 29 provincial regions of China from 2008 to 2017 (Based on the availability of data, excluding Hong Kong, Macau, Taiwan, Hainan and Tibet).The data related to environmental tax are from "China Environmental Statistical Yearbook" and "China Statistical Yearbook". The relevant data of green process innovation are mainly from the "Industrial Science and Technology Activity Statistical Yearbook" and "China Science and Technology Statistical Yearbook", government innovation subsidies and the relevant data of the variables involved in the control variables are from "China Industrial Statistics Yearbook", "China Science and Technology Statistics Yearbook" and "China Environmental Statistics Yearbook", all variables are processed by logarithm.

\subsection{Variable measurement}

Explained variable: Enterprise Green Process Innovation (Tech),according to the existing research, the green process innovation (Tech) referred to in this research is a process to reduce the discharge of waste water, waste gas and solid waste. Through the upgrading of equipment and technology in key links, the green transformation of production process is carried out, the green degree of the process technology is upgraded,and "three wastes" is recycled and so on. Therefore, the sum of $R \& D$ internal funds and technical transformation funds can be used to test the degree 
of innovation in green processes. Because the technological progress led by $R \& D$ internal expenditures is not necessarily the direction of green process development.Refers to the research of Wang and Guo(2016), green process innovation is measured by the ratio of technological transformation investment and industrial industry added value at the same time, which can avoid the influence of the scale difference between industries in different regions on the research results. The larger the ratio, the higher the degree of green process innovation.

Explanatory variable (threshold variable):Environmental tax (St),Resource tax, land use tax and cultivated land occupation tax are related to the environment,can directly reflect the environmental tax and green technology innovation of enterprises. Therefore, the sum of resource tax, land use tax and cultivated land occupation tax is selected as the substitute variable of environmental tax, and the amount of resource tax in the fiscal revenue and expenditure of each province as an alternative index of environmental tax to explore the impact on the research object; Government innovation subsidies ( Gov),Referring to the research by Liu (2019), the proportion of government funds in the internal expenditure of R\&D funds.

Control variables: Regional economic development level (GDP).Regional per person GDP can show the different levels of regional economic development. Whether enterprises have a favorable innovation environment is closely related to the development of regional economy; Enterprise size (Size).It is expressed by the ratio of the main business income and the number of enterprise of industrial enterprises above the scale in each region, because enterprises with larger scale have the ability to invest more resources in green $R \& D$,so as to promote green process innovation; Human capital level (HCS).It is reflected by the education level of employees in each region and it is measured by the number of years of per person of employees in each region.; The degree of opening to the outside world (Trade), it is measured by the proportion of the total import and export of each region in the regional GDP over the years.

\subsection{Threshold model}

On the basis of the above analysis, when we study the impact of two independent variables, environmental tax and government innovation subsidies, on green process innovation of enterprises, the impact of a single independent variable on green process innovation of enterprises may also change after adding another independent variable. Therefore, there may be a nonlinear relationship. For this kind of test, the method of grouping test or interactive item is generally used, but the grouping test has an error when dividing the interval, and the interactive item ultimately 
reflects the monotonic relationship between variables. Therefore, this research constructs a panel threshold model for analysis, which can divide the interval according to the characteristics of the data itself. The following are the basic principles of the single threshold model:

Single threshold model takes Sc as explanatory variable and Gov as threshold variable:

$\operatorname{lgTech} \mathrm{Tt}_{\mathrm{it}}=a_{1} \operatorname{lgGDP}_{\mathrm{it}}+\mathrm{a}_{2} \operatorname{lgSize}_{\mathrm{it}}+\mathrm{a}_{3} \operatorname{lgHCS}_{\mathrm{it}}+\mathrm{a}_{4} \operatorname{lgTrade}_{\mathrm{it}}+\theta_{1} \operatorname{lgSc}\left(\operatorname{lgGov} \leqslant \eta_{1}\right)$

$+\theta_{2} \operatorname{lgSc}\left(\operatorname{lgGov}>\eta_{1}\right)+\mathrm{u}_{\mathrm{i}}+\varepsilon_{\text {it }}$

Single threshold model takes Gov as explanatory variable and Sc as threshold variable:

$1 \mathrm{gTech} \mathrm{it}_{\mathrm{it}}=\mathrm{a}_{1} 1 \mathrm{gGDP}_{\mathrm{it}}+\mathrm{a}_{2} 1 \mathrm{gSize} \mathrm{it}_{\mathrm{it}}+\mathrm{a}_{3} \operatorname{lgHCS}_{\mathrm{it}}+\mathrm{a}_{4} 1 \mathrm{gTrade} \mathrm{it}_{\mathrm{t}}+\theta_{1} \operatorname{lgGov}\left(\operatorname{lgSc} \leqslant \eta_{1}\right)$

$+\theta_{2} \operatorname{lgGov}\left(\operatorname{lgSc}>\eta_{1}\right)+\mathrm{u}_{\mathrm{i}}+\varepsilon_{\text {it }}$

Among them, "Tech ${ }_{i t}$ "is the explained variable. "GDP ${ }_{i t}$ ", "Size $e_{i t} ", \mathrm{HCS}_{\mathrm{it}}$ " and "Trade ${ }_{\mathrm{it}}$ " are the control variables. " $u_{i}$ " is the individual fixed effect. " $\varepsilon$ it"is the random error term. "i" represents the provinces. " $\mathrm{t}$ " represents the time. Both the double threshold model and the multiple threshold model are based on the single threshold model and there will not be described in detail.

\section{Empirical research and Results}

\subsection{Descriptive statistical analysis}

Descriptive statistical analysis of all variables reveals an obvious characteristic from Table 1. The standard deviation of environmental tax is relatively large, which indicates that there are large differences in environmental tax among regions. This is due to the different level of regional development and different degrees severity of government policies.

Table 1 Results of descriptive statistics of the sample $(2008-2017, N=29, T=10, N T=290)$

\begin{tabular}{cccccc}
\hline $\begin{array}{c}\text { Variable } \\
\text { name }\end{array}$ & Meaning of variable & Average value & $\begin{array}{c}\text { Minimum } \\
\text { value }\end{array}$ & $\begin{array}{c}\text { Maximum } \\
\text { value }\end{array}$ & $\begin{array}{c}\text { Standard } \\
\text { deviation }\end{array}$ \\
\hline Tech & Green Process Innovation & 0.019 & 0.002 & 0.107 & 0.0140 \\
Sc & Environmental Tax & 8.685 & -8.000 & 10.436 & 2.8732 \\
Gov & Government Innovation & -0.631 & -1.163 & -0.003 & 0.2970 \\
& Subsidy & & & & \\
GDP & Level of economic & 4.596 & 3.974 & 5.110 & 0.2250 \\
& development in the region & & & & \\
Size & Enterprise size & 0.384 & -0.247 & 1.231 & 0.2218 \\
HCS & Human capital level & 0.980 & 0.843 & 1.640 & 0.0649 \\
Trade & Opening degree & -0.768 & -2.846 & 0.230 & 0.4423 \\
\hline
\end{tabular}

5.2 Threshold effect analysis and Hypothesis verification results

\subsubsection{Hausman test}


Because the null hypothesis of Hausman test is a random effect, the result shows that the $\mathrm{P}$ value is less than 0.05 . That is to say the null hypothesis is rejected at the $95 \%$ level, so the fixed effect model is used.

Table 2 Hausman test

\begin{tabular}{ccc}
\hline Hausman test & Chi-square value & p-value \\
\cline { 2 - 3 } & $13.47^{* *}$ & 0.036 \\
\hline
\end{tabular}

Note: $* * *$, and $* * *$ indicate significance at $10 \%, 5 \%$, and $1 \%$ levels, respectively.

\subsubsection{Fixed effect model}

The fixed effect model examines the impact of environmental tax and government innovation subsidies on enterprise green process innovation, and the results are shown in Table 3. Model one is the impact of environmental tax on enterprise green process innovation, and model two is the impact of government innovation subsidies on enterprise green process innovation. The environmental tax coefficient in Model 1 is -0.010 , which shows that the environmental tax policy has a negative impact on the green process innovation of enterprises, which validates H1. The coefficient of government innovation subsidies in Model 2 is 0.014 , which shows that the government innovation subsidies policy has a positive impact on the green process innovation of enterprises, verifying $\mathrm{H} 2$.

\section{Table 3 Fixed effects model}

\begin{tabular}{ccccccc}
\hline \multirow{2}{*}{$\begin{array}{c}\text { Explanatory } \\
\text { variable }\end{array}$} & \multicolumn{3}{c}{ Model one } & \multicolumn{3}{c}{ Model two } \\
\cline { 2 - 7 } $\lg$ Coefficient & $\mathrm{t}$ value & P value & Coefficient & $\mathrm{t}$ value & P value \\
\hline $\lg$ gGov & $-0.010^{*}$ & -2.04 & 0.051 & - & - & - \\
$\lg$ GDP & - & - & - & 0.014 & 1.70 & 0.101 \\
$\operatorname{lgSize}$ & -0.014 & -1.49 & 0.147 & $-0.042^{* * *}$ & -4.71 & 0.000 \\
$\operatorname{lgHCS}$ & $-0.018^{* * *}$ & -3.07 & 0.005 & 0.001 & 0.03 & 0.973 \\
$\lg$ Trade & $0.003^{* * *}$ & -0.01 & 0.995 & -0.009 & -1.51 & 0.142 \\
$\mathrm{R}^{2}$ & & 3.62 & 0.001 & 0.001 & 0.38 & 0.704 \\
Fvalue & & 0.4972 & & & 0.4958 & $50.35^{* * *}$ \\
\hline
\end{tabular}

\subsubsection{Threshold effect test}

First, taking environmental tax as the threshold variable, and government innovation subsidy as the explanatory variable. The test results show that the single, double, and triple thresholds fail to passed the $10 \%$ significance test, so there is no threshold in this model. 
Then, taking government innovation subsidy as the threshold variable and environmental tax as the explanatory variable, the test results show that the single threshold test has $5 \%$ significance, the double threshold test has $1 \%$ significance, and the triple threshold fails $10 \%$ significance test. It shows that take government subsidy innovation as the threshold variable, there are two thresholds in the selected samples.

Because there is no threshold in the model of environmental tax as threshold variable, but there are two threshold values in the model with government innovation subsidy as threshold variable. Therefore, in the following empirical research, we only analyze the model with government innovation subsidy as threshold variable and environmental tax as explanatory variable.

Table 4 Test result of threshold effect

\begin{tabular}{ccccccc}
\hline \multirow{2}{*}{$\begin{array}{c}\text { Threshold } \\
\text { variable }\end{array}$} & Threshold number & F value & P value & \multicolumn{3}{c}{ Critical value } \\
\cline { 5 - 6 } & & & & $1 \%$ & $5 \%$ & $10 \%$ \\
\hline Environmental tax & Single threshold & 12.49 & 0.2067 & 16.191 & 21.068 & 26.922 \\
$(\operatorname{lgSc})$ & Double threshold & 5.24 & 0.577 & 11.876 & 14.224 & 26.969 \\
& Triple threshold & 5.01 & 0.453 & 9.736 & 11.764 & 22.300 \\
Government & Single threshold & $36.284^{* *}$ & 0.037 & 47.655 & 30.401 & 26.126 \\
innovation & Double threshold & $77.59^{* * *}$ & 0.000 & 36.758 & 24.382 & 18.527 \\
subsidies (lgGov) & Triple threshold & 13.12 & 0.173 & 40.663 & 19.977 & 16.874 \\
\hline
\end{tabular}

\subsubsection{Threshold value estimation results}

Taking government innovation subsidies as threshold variables, the estimated thresholds and corresponding 95\% confidence intervals are shown in Table 5 below. All variables are logarithmic processing, so the threshold interval is expressed as three change intervals of $\operatorname{lgGov}$ it. They are $\operatorname{lgGov} \leq-0.590$ (the first interval), $-0.590<\operatorname{lgGov} \leq-0.075$ (the second interval) and $\operatorname{lgGov}>-0.075$ (the third interval).

Table 5 Threshold value estimation results

\begin{tabular}{cccc}
\hline \multicolumn{2}{c}{ Threshold variable } & Estimate & 95\% confidence interval \\
\hline Government innovation & Threshold value 1 & -0.075 & {$[-0.087,-0.068]$} \\
subsidy (lgGov) & Threshold value 2 & -0.590 & {$[-0.623,-0.582]$} \\
\hline
\end{tabular}

\subsubsection{Parameter estimation results of the model}

Table 6 Threshold model parameter estimation results

\begin{tabular}{cccc}
\hline $\begin{array}{c}\text { Explanatory variable } \\
\text { cat\#c.Sc }\end{array}$ & coefficient & T value & \\
1 & & & \\
2 & $0.015^{* * *}$ & 4.63 & 0.000 \\
\hline
\end{tabular}




\begin{tabular}{cccc}
\hline 3 & -0.001 & -0.05 & 0.958 \\
$\operatorname{lgGDP}$ & $-0.056^{* * *}$ & -7.44 & 0.000 \\
$\operatorname{lgSize}$ & -0.001 & -0.23 & 0.817 \\
$\lg \mathrm{HCS}$ & -0.010 & -0.84 & 0.401 \\
$\lg$ Trade & 0.001 & 0.54 & 0.589 \\
$\mathrm{R}^{2}$ & & 0.5227 & \\
F value & & $34.63^{* * *}$ & \\
\hline
\end{tabular}

As shown in Table 6, cat\#c.Sc represents the interaction relationship between environmental tax and government innovation subsidies. When the government innovation subsidy is $\operatorname{lgGov}>-0.075$, the interaction between the two has a negative impact on the enterprise green process innovation. When the government innovation subsidy is $-0.590<\operatorname{lgGov} \leq-0.075$, the interaction between them has a positive impact on the green process innovation of the enterprise, and when the government innovation subsidy is $\lg G o v \leq-0.590$, the coefficient of the interaction term is the largest. In model 1, the impact coefficient of environmental tax on enterprise green process innovation is 0.010 . In model 2 , the impact coefficient of environmental tax on enterprise green process innovation is 0.014 . And the optimal positive impact of the interaction of environmental tax and government innovation subsidies on enterprise green process innovation of is 0.015 , which is greater than the impact of environmental tax or government innovation subsidies respectively on enterprise green process innovation. Therefore it is verified that there is a moderate range of the nonlinear relationship between environmental tax and government innovation subsidy and the effect of policy implementation.

The regional economic development level, enterprise scale and human resource level have a negative impact on enterprise green process innovation, while the degree of opening to the outside world has a positive impact on enterprise green process innovation. However, the influence of the enterprise scale, human resources level and opening degree are not significant. The degree of openness to the outside world reflects the distance between regional enterprises and technological frontiers. When this distance is small, it has a more positive impact on green process innovation. However, the more advanced technology is, the more difficult to imitate and the more independent innovation ability is needed. So the impact of variable is not significant. The higher the level of regional economic development, the more types and quantities of products, the more complex the design of production process technology. Under the government environmental regulations, enterprise need to meet the standards on environmental related regulations, In the early stage, more funds and technology will be invested in green product innovation involving products from 
design and development to the market, compared with the process equipment modification and waste recycling and other more complex innovation, the effect will be more obviously and the process will be more operational. However,in areas with lower economic level,the enterprise technology is generally relatively simpler. Therefore, in the process of investing in process innovation, the cost is lower than that innovation in a series of links from product design and R\&D to the market. At the same, it time can meet the green index standard of final product. So it is more likely to enterprises are more inclined to invest more resources in green process innovation. For the two factors of human resource level and enterprise scale, they will increase with the improvement of regional economic level. The impact of regional economic level on green process innovation is also applicable to human capital level and enterprise scale.

\subsubsection{The distribution status and characteristics of each provincial region in the}

\section{threshold interval}

As shown in Table 7, the number of provincial regions distributed in three different intervals divided by threshold in different periods of 2008-2017 is listed. It can be seen that this number also has a great difference with the change of time time. This shows that the threshold model is more scientific and reasonable, because it can divide the interval according to the characteristics of the data itself, and avoid errors caused by artificial grouping. Taking government innovation subsidies as the threshold variable, the distribution of each province in its region shows a certain regularity. Firstly, after 2011, most provinces are in the first interval, that is, the optimal interval analyzed previously, which shows that the government innovation subsidies of most provinces are established in the most appropriate interval. Secondly,as time goes by, the provinces in the third interval have gradually shifted to the first and second intervals, which shows that the current environmental tax policies of all provinces can effectively promote enterprise green process innovation under the influence of government innovation subsidies. But nearly half of the provinces are still not in the optimal range. That is, under the government innovation subsidies, the environmental tax has the greatest promotion effect on promoting on green process innovation of enterprises.

Table 7 Distribution status and changes of each provincial region in the threshold interval

\begin{tabular}{ccccc}
\hline $\begin{array}{c}\text { Threshold } \\
\text { interval }\end{array}$ & 2008 & 2011 & 2014 & 2017 \\
\hline lgGov $\leqslant-0.590$ & 20 & 20 & 15 \\
& Newly added: Fujian, & Newly & Newly added: \\
\hline
\end{tabular}




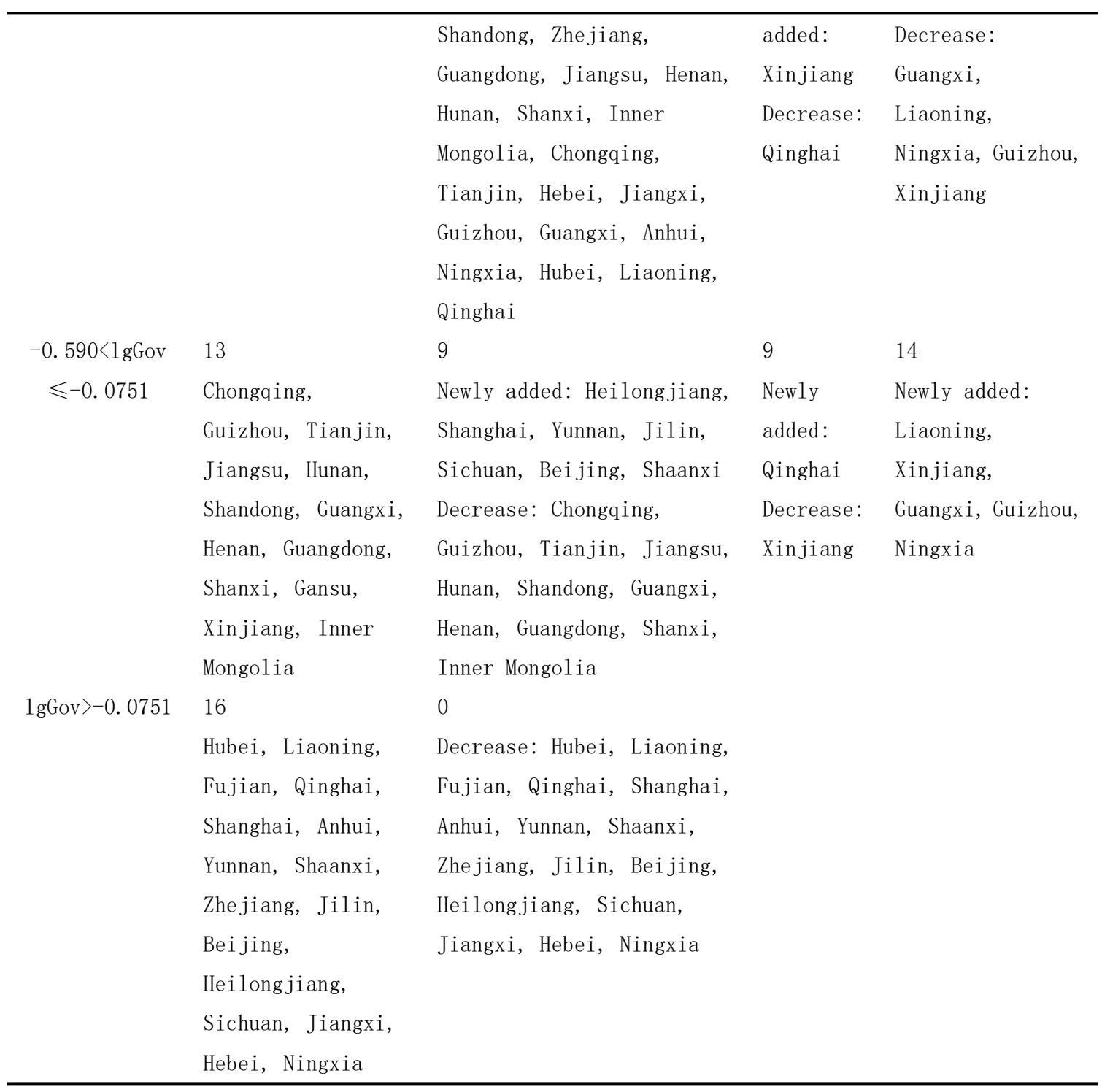

\section{Conclusions and recommendations}

\subsection{Research conclusion}

Based on the analysis of the data of 29 provincial regions in 2008-2017, this research constructs a nonlinear double threshold model to test the impact of environmental tax and government innovation subsidies on green process innovation of enterprises. The conclusions are as follows:

The implementation of environmental tax policy alone has a negative impact on enterprise green process innovation: at this time, environmental tax may cause excessive cost pressure on enterprise.When enterprises lack sufficient funds, it will have a negative attitude towards green process.

The implementation of government innovation subsidies alone has a positive effect on enterprise green process innovation: green process innovation requires 
long-term and large amounts of capital investment, so government subsidies can alleviate the cost pressures of enterprises due to innovation;Government innovation subsidy policy will guide enterprises to actively carry out green process innovation. Government innovation subsidies can make up for the externalities which generated by enterprises carry out green innovation activities.

When the environmental tax is the core explanatory variable and the government innovation subsidy is the threshold variable, the interaction between environmental tax and government innovation subsidy on enterprise green process innovation can be divided into three stages, and when the government innovation subsidy is low, the environmental tax has the greatest positive impact on enterprise green process innovation: under the regulation of environmental tax, enterprise will increase their awareness of green transformation; The results shows that the government innovation subsidies can support enterprise to carry out further green process innovation; Environmental tax and government innovation subsidies interact when they jointly affect green process innovation, forming a more efficient portfolio policy.

\subsection{Recommendations}

Environmental tax and government innovation subsidy policy should be implemented in coordination. When making decisions, enterprises will also consider the impact of tax and subsidy policies on costs, operations and future development. In the empirical study, after adding the influence of government innovation subsidies, the environmental tax which adversely affects the enterprise green process innovation has a positive effect. Therefore, cooperating with the implementation of environmental tax and government innovation subsidy policy can have a stronger promotion effect on enterprise green process innovation.

Environmental tax and government innovation subsidy policy should be implemented in different regions and stages. The green transformation of enterprises need to adapt to the process. Among the three regions divided by the threshold, the first region is the most suitable interval, and the provinces in the third region have all transferred to the first or second region after 2011. Therefore, the provinces in the optimal range should continue to maintain policies related to environmental tax and government innovation subsidies. When promoting green transformation of regional enterprises which are not yet in the optimal range, it is necessary to pay attention to the 
fact that if local enterprises directly face high-intensity policies, the cost issue may become an adverse factor affect enterprise green transformation decision-making. Therefore, when enterprises already have a certain degree of green innovation awareness and technical capabilities, we can adjust the relevant policies of environmental tax and government innovation subsidies,so that enterprises can move towards the direction of deep innovation.

Improve the green innovation environment of market.Through providing technical support or green technology loans or other means and measures,government can improve the awareness of green transformation, help enterprises promote the process of green transformation and adapt to the difficulties that may be faced in the green transformation, encourage enterprises to seize opportunities of green innovation and carry out green process innovation.So that enterprises can do a good cognitive foundation and technical reserves for deep innovation.

\section{Acknowledgement: This research was funded by "The National Social Science Fund Project} of China"(Grant number 16BJY024) .

\section{REFERENCES}

[1] Poter, Linde, 1995. Toward a New Conception of the Environment-Competitiveness Relationship[J]. Journal of Economic Perspectives, 9 (4) :97-118.

[2] Margat, 1978. Pollution control and technological advance:a dynamics model of the firm [J] .Journal of Environmental Economics and Management,5(1):1-25.

[3] Xing,L., Yu,H., 2019. Influence of Environmental Regulation on Green Innovation - - The Moderating Role of Green Dynamic Capability [J].East China Economic Management,33(10):20-26.

[4] Qu,X.C., Hou,G.S., Sun,X.Y., 2019. Evolutionary Game Analysis of Green Innovation Ecosystem of Enterprises under Government Regulation:Analysis from the Perspective of Initial Willingness Differentiation [J].Systems Engineering,(06):1-15.

[5] Zhang,F., Shi,Z.W., Song,X.N., Yan,X.X., 2019. Green Technology Innovation Efficiency of Advanced Manufacturing and its Environmental Regulation Threshold Effect [J].Science \& Technology Progress and Policy ,36(12):62-70.

[6] Li,R.Q., 2019. Environmental Regulation,Institutional Quality and Green Technology Innovation [J].Modern Economic Research,(10):19-27.

[7] Li,Y.N., Lin,J.,Qian, Y.J., 2019. Manufacturer ' s Green Production Decision under Environmental Regulation and the Influence of Technology Learning Factors [J].Chinese Journal of Management,16(05):721-727.

[8] Tullock,1967.Excess Benefit[J].Water Resource Research, (3) .

[9] Kneese, Bower, 1968. Managing Water Quality:Economics, Eechnology and Institutions[M].Baltimore:The John Hopkins University Press. 
[10] Terkla, 1984. The Efficiency Value of Effluent Tax Revenues[J].Journal of Environmental Economics and Manage-ment, (11) :107-123.

[11] Pearce, 1991. The Role of Carbon Taxes in Adjusting to Global Warming[J].Economic Journal, 101 (407) :938-948.

[12] Li,X.J., He,N., 2018. Regional competition environmental tax and enterprise green technology innovation [J].China Population,Resources and Environment,28(09):73-81.

[13] Leeuwen,G.V., Mohen,P., 2013.Revisiting the Porter Hypothesis:An Empirical Analysis of Green Innovation for the Netherlands[J].Economics of Innovation\&New Technology,67 (2) :295-319.

[14] Chen,X., Li,M., Zhang,Z.Z., 2019. Environmental Regulation,Government Subsidies and Green Technology Innovation-—Empirical Research Based on the Mediation Effect Model [J]. Journal of Industrial Technological Economics, 38(09):18-25.

[15] Acemoglu D,P Aghion, 2012. The Environment and Directed Technical Change[J].The American Economic Review,102(1):131-166.

[16] Duan, N.N., Xu,F.Y., Ni, M., 2016. Evolutionary game analysis of enterprises' relationship on Green Technological Innovation based on knowledge spillover effcet [J]. Science and Technology Management Research, 36(20):157-163.

[17] Liu,J.R., Zeng,X.F., Zeng,Q., 2019. Influence of Environmental Regulation and Government Innovation Subsidy on Enterprise Green Product Innovation [J]. Research on Economics and Management ,40(06):106-118.

[18] Qin,S.S.,2012. Policy Support of Green Technology Innovation [J].Science \& Technology and Economy ,25(01):18-21.

[19] Li,H.X.,2014. Green technology innovation of private enterprises and environmental tax policy [J].Taxation Research,(03):12-15.

[20] Xu,J.Z., Guan,J., Zhu,X.Y., 2017. Evolutionary Game Analysis on Impacts of Government Regulation on Enterprises' Environmental Innovation Mode Selection [J].Operations Research and Management Science,26(09):68-77.

[21] Shi,L.L., Zhao,J., 2018. Environmental regulation,technological innovation and industrial structure upgrading [J].Science Research Management, 39(1):119-125.

[22] Li,Y.F., 2019. Impact of Innovation Subsidy on Technological Innovation of Agricultural Products Processing Enterprises [D].Fujian Agriculture and Forestry University.

[23] Antonelli, Crespi, 2013. The "Matthew effect" in R\&D public subsidies:The Italian evidence[J].Technological Forecasting and Social Change,80(8):1523-1534.

[24] Wang,F.Z., Guo,X.C., 2016. Government Governance,Environmental Regulation and Green Process Innovation [J].Journal of Finance and Economics, 42(09):30-40.

[25] Clausen.,Schürenberg-Frosch,H.Aid,2012. Spending Strategies and Productivity Effects:A MultiSectoral CGE Analysis for Zambia[J].Economic Modelling,(29):2254-2268.

[26] Hansen, 1999. Threshold effects in non-dynamic panels: estimation,testing,and inference[J].Journal of Econometric,93(2) :345-368.

[27] Kuang,C.E., Wen,Z.Z., Peng,W.B., 2019. Threshold effect of shadow economy on green innovation efficiency [J].Economic Geography,,39(7):184-193.

[28] Ren,S.M., Lv,Z., 2014. The Financial Constraints, the Government Subsidies and the Factor Productivity:A Case Study on the Equipment- Manufacturing Enterprises in China [J]. Management World(11):10-23. 
